\title{
Service Quality Assessment at the Learning Resourse Center in Can Tho University, Vietnam
}

\author{
Thi Trang Huynh ${ }^{1}$, Mai Huynh Nguyen ${ }^{2}$, Bang Duy Vo ${ }^{3}$ \\ $*^{1 \& 2}$ School of Social Sciences and Humanities Can Tho University, Vietnam \\ ${ }^{* 3}$ Learning Resource Center, Can Tho University, Vietnam
}

\begin{abstract}
This paper reports the findings of assessing the quality of services offered at an academic library in the Mekong Delta, Vietnam. Using the quantitative approach, 31 criteria of updated LibQual model were considered in this research. Data collected in this study include online survey of 386 students from different courses and majors in the university. Research findings indicate that students were satisfied with all library services at a high level. The findings also reveal that there were 4 groups of factors influencing students' satisfaction. They were Service Affect, Information Control, Library as a Place and Copyright. Of the four influential factors, Service Affect was identified as the strong factor while Information Controll was found to be the minor. Some implications for administrators and librarians are also provided with particular regard to the assessment of the quality of library services.
\end{abstract}

Keywords -- assessment, Influencing factors, LibQual model, services, ServQual model, quality

\section{INTRODUCTION}

Collecting users' assessment on the quality of library services is a regular work at libraries, including the Learning Resource Center of Can Tho University. The evaluation is aimed at improving and developing library services to serve users more efficiently and friendly. Can Tho Learning Resource Center has operated many services and launched the online assessment survey to receive feedback and comments from the users. However, the number of participants being involved in the survey was quite limited and the evaluation responseswere modest. It is therefore necessary to conduct a larger scale surveywith more observed items to make timely changesto the improments in the efficiency of library services in order to meet the various needs of the users in the digital age.

The study on evaluation of service quality is crucial since it benefits teachers, students, library leaders, and the university administrators. First, this study is significant because it will help teachers know how to approach and process library resources for their teaching to facilitate student learning in the field. As students know all of the services available at the library, they can plan to use these accessible sources for their own learning and research. This study may provide library leaders with insights into the current situation and conditions of information resources, learning environment and users' copyright commitment. As a result of such benefits, library leaders are likely to develop and improve services for student users. The findings from this study will help the university administrators consider how to provide financial support or budget to the library to enhance the quality of library services through training workshops or seminars.

\section{METHODOLOGY AND LITERATURE REVIEW}

Research has indicated that several models are widely usedto assess the quality of services. These include ServQual, LibQual, ServPerf, WebQual, Lib-PerfQual, SiteQual, DigiQual, StatsQual, MINES and ClimateQual. ServQual andLibQual are two common ones withtheir own strengths and weaknesses. ServQual is a model mostly used in marketing and then applied in other areas [11]. ServQual survey questionnaire includes 22 criteria with 5 dimensions: tangibility, reliability, responsiveness, assurance, and empathy. The model determines the gap between the user's expectations and the actual services provided by the library. This tool helps the library leader know how customers feel about the provided services and how responsive they are to users' expectation [4], [14]. However, 
DOI: $\underline{10.51386 / 25815946 / i j s m s-v 4 i 4 p 109}$

Volume: 4 Issue: 4

July to August 2021

https://www.ijsmsjournal.org

Reference [5]claim that ServQual can work in an industrial environment, but not in a library. Various studies have proven that the fivedimensions of ServQual do not cover all of the contents to be investigated in the context of a library and there is a need for additional quality dimensions [6].

With 22 criteria, LibQual measures library users' satisfaction of service quality through three dimensions: Affect of service, Information control and library as a place. For each criterion, the user indicates the minimum service level, the desired service level, and the perceived service performance. LibQual is used to determine the gap between the customer's expectations and the perception of the actual service received. Usually, customers' perception of service quality is mainly estimated, so finding the gap between their expectations and perceptions is not completely accurate [18]. Further more, ServQual and LibQual are used to measure the service quality of each aspect of the library. These models are not to measure the entire and large library system [10].

In Vietnam, evidence shows that ServQualand LibQual wereapplied, evaluated and updated to fit with library settings [1], [2], [3], [9], [15], [16]. In this study, an updated model including 22 items, 3 dimensions of LibQual (Service Affect, Information Controll, and Library as a Place) combined with9 additional items and one dimension (Copyright)was examined and accepted by a cohort of academic librarians to suit the Vietnamese academic library environment in the digital age. Most items and dimensions are from LibQual, so it isnamed the updated LibQual model. In this study, the LibQual modelwas used to measure the level of satisfaction of the learners towards library services as well as the influencing factors to their satisfaction. Nine additional items are italicized in Table 2.

\section{METHODS}

This study was conducted using quantitative approach. An online survey was delivered to 37,000 undergraduates and post-graduatesof the university by email. As suggested by Reference [13], the minimum sample of this research is 380. 386participants completed the survey. Of the total, 197 were females (51\%) and 189 males (49\%). Most of them were juniors $(n=165 ; 42.7 \%)$ and seniors $(n=91 ; 23.6 \%)$. Only $11.1 \%(n=43)$ of them were sophomores. The participants were from College of Engineering Technology, College of Economics and College of Information and Technology. None of them are from School of Pre-University, Department of Physical Education and Mekong Delta Development Research Institute.

Data collected from the online survey were analysed using SPSS functions such as frequency, correlation, Mean, descriptive statistical analysis, exploratory factor analysis (EFA) and multivariate regression analysis to answer the research questions. Cronbach's Alpha in Tablelis 0.985, indicating that the reliability of the questionnaire was high and acceptable for conducting research and collecting data [8].

Table 1: Reliability Statistics(Cronbach's Alpha)

\begin{tabular}{|c|c|}
\hline Cronbach's Alpha & $\mathrm{N}$ of Items \\
\hline .985 & 65 \\
\hline
\end{tabular}

\section{FINDINGS}

1) Assessment of library service quality bythe updated LibQual model

Table 2: Library service quality by the updated LibQual model

\begin{tabular}{|c|l|l|c|c|c|c|c|c|}
\hline No & Dimension & \multicolumn{1}{|c|}{ Criteria } & $\mathbf{( 1 )}$ & $\mathbf{( 2 )}$ & $\mathbf{( 3 )}$ & $\mathbf{( 4 )}$ & $\mathbf{( 5 )}$ & Mean \\
\hline \multirow{5}{*}{1} & \multirow{4}{*}{$\begin{array}{l}\text { Service } \\
\text { Affect }\end{array}$} & Employees who instill confidence in users & 0 & 7 & 109 & 147 & 123 & 4.00 \\
\cline { 3 - 8 } & Giving users individual attention & 0 & $\mathbf{1 9}$ & 100 & 140 & 127 & 3.97 \\
\cline { 3 - 8 } & Employees who are consistently courteous & 0 & 9 & 65 & 152 & 160 & 4.20 \\
\cline { 3 - 9 } & Readiness to respond to users' questions & 0 & $\mathbf{1 9}$ & 49 & 130 & 188 & 4.26 \\
\cline { 3 - 9 } & $\begin{array}{l}\text { Employees who have the knowledge to answer } \\
\text { user questions }\end{array}$ & 0 & 6 & 97 & 149 & 134 & 4.06 \\
\cline { 3 - 9 } & $\begin{array}{l}\text { Employees who understand the needs of their } \\
\text { users }\end{array}$ & $\mathbf{6}$ & 11 & $\mathbf{1 5 6}$ & 129 & 84 & 3.71 \\
\hline
\end{tabular}




\begin{tabular}{|c|c|c|c|c|c|c|c|c|}
\hline & & Willingness to help users & 0 & 7 & 104 & 130 & 145 & 4.07 \\
\hline & & Dependability in handling users' service problems & 1 & 6 & 109 & 133 & 137 & 4.03 \\
\hline & & Capacities to help users' online-study & 5 & 10 & 146 & 140 & 85 & 3.75 \\
\hline & & Employees who deal with users in a caring fashion & 0 & 1 & 31 & 133 & 221 & 4.49 \\
\hline \multirow{10}{*}{2} & \multirow{10}{*}{$\begin{array}{l}\text { Information } \\
\text { Control }\end{array}$} & The printed materials I need for my work & $\mathbf{1}$ & 14 & 65 & 142 & 164 & 4.18 \\
\hline & & $\begin{array}{l}\text { Print and/or electronic journal collections I need } \\
\text { for my work }\end{array}$ & 0 & 9 & 103 & 139 & 135 & 4.04 \\
\hline & & $\begin{array}{l}\text { Making electronic resources accessible from my } \\
\text { home or office }\end{array}$ & 0 & 9 & 103 & 124 & 150 & 4.08 \\
\hline & & The electronic information resources I need & 0 & 9 & 96 & 137 & 144 & 4.08 \\
\hline & & Reliable electronic resources & 6 & 12 & 131 & 116 & 121 & 3.87 \\
\hline & & Available data that allow me to work on my own & 0 & 8 & 101 & 145 & 132 & 4.04 \\
\hline & & $\begin{array}{l}\text { Modern equipment that lets me easily access } \\
\text { needed information }\end{array}$ & 0 & 8 & 101 & 123 & 154 & 4.10 \\
\hline & & $\begin{array}{l}\text { Easy-to-use access tools that allow me to find } \\
\text { things on my own }\end{array}$ & 4 & 11 & 128 & 122 & 121 & 3.89 \\
\hline & & Making information easily accessible for use & 0 & 1 & 30 & 122 & 233 & 4.52 \\
\hline & & $\begin{array}{l}\text { A library Website enabling me to locate } \\
\text { information on my own }\end{array}$ & 2 & 7 & 95 & 122 & 160 & 4.12 \\
\hline \multirow{7}{*}{3} & \multirow{7}{*}{$\begin{array}{l}\text { Library as a } \\
\text { Place }\end{array}$} & Quiet space & 9 & 13 & 121 & 115 & 128 & 3.88 \\
\hline & & A comfortable and inviting location & 0 & 8 & 87 & 113 & 178 & 4.19 \\
\hline & & A getaway for study, learning, or research & 0 & 6 & 93 & 102 & 185 & 4.21 \\
\hline & & Library space inspires study and learning & 5 & 11 & 123 & 110 & 137 & 3.94 \\
\hline & & Library space inspires study and research in group & 1 & 0 & 36 & 116 & 233 & 4.50 \\
\hline & & Friendly website & 1 & 7 & 101 & 130 & 147 & 4.08 \\
\hline & & Useful website & 4 & 6 & 79 & 130 & 167 & 4.17 \\
\hline \multirow{4}{*}{4} & \multirow{4}{*}{ Copyright } & Useful information for everyone & 0 & 5 & 86 & 128 & 167 & 4.18 \\
\hline & & Open access information & 6 & 9 & 122 & 123 & 126 & 3.92 \\
\hline & & Trust veracity of content & 0 & 8 & 91 & 123 & 164 & 4.15 \\
\hline & & Contents with experts and users' evaluations & 0 & 7 & 102 & 139 & 138 & 4.06 \\
\hline
\end{tabular}

In general, 31 assessment criteria of library services were scored at good and very good scales. Of the total, 5 criteria were recorded at very good point with regard to the quality (Mean > 4.21) and 26 criteria at good point $(M=3.41-4.20)$. The criterion Library makes information easily accessible for use reached the highest score $(M=$ 4.52). Ranked the second at the very good quality is the Library space that inspires study and research in group $(M=4.50)$. The Employees who deal with users in a caring fashion was the criterion ranked at the third place with an average score of 4.49. In addition, Library staff's readiness to respond to users' questions $(M=4.26)$ was the fourth most appreciated criterion. Ranked the fifth in the good quality list was the criterion that Library is a getaway for study, learning, or research $(M=4.21)$. Thus, in the top 5 criteria of good quality performance, there were two criteria in the dimension of Library as a Place, two criteria in the dimension of Service Affect and only one criterion in the dimension of Information Control. None of the criteria in the dimension of Copyright were rated very well by the users. This shows that the users were very interested in and considered the library as a place for study and research, and that the support of librarians and equipment were found to help usersaccess information rather than the copyright of information sources.

Although all service evaluation criteria of the library were rated at good and very good scales by the students, some criteria needed to be considered. Specifically, 6 of 10 criteria in the dimension of Service Affectwere rated at medium quality by more than 100 users (> 25\%). Of the total, the criteria of Employees who understand the needs of their users $(\mathrm{n}=156 ; 40.4 \%)$ and Capacities to help users' online-study $(\mathrm{n}=146 ; 37.8 \%)$ werescored at the 
medium level. Moreover, a number of students ranked these two criteria at bad and very bad quality, like Library staff who understand the needs of their users $(\mathrm{n}=17 ; 4.4 \%)$ and Staff's capacities to help users' online-study ( $\mathrm{n}$ $=15 ; 3.9 \%)$. In addition, nearly $5 \%$ of the students participating in the survey $(\mathrm{n}=19 ; 4.9 \%)$ ratedbadly to the library staff in two criteria: Giving users individual attention and Readiness to respond to users' questions. Therefore, this suggests that library leaders need to consider how to improve their staff's work-adaption capacity.

Similarly, in the dimension of Information Control, two criteria were rated badly by the majority of students. They were the criterion of Library reliable electronic resources and Easy-to-use access tools that allow me to find things on my own. More specifically, the criterion of Library reliable electronic resourceswas recorded at $38.6 \%(\mathrm{n}=139)$ of students rating from level (1) to level (3) in which 131 students $(33.9 \%)$ rated so so, $12(3.1 \%)$ rated badly and $6(1.6 \%)$ rated very badly. To the criterion of Easy-to-use access tools that allow me to find things on my own, 128 students $(33.2 \%)$ rated average, $11(2.8 \%)$ rated bad quality and $4(1 \%)$ students rated very bad quality.

In Library as a Place, three criteria received the average rating with more than 100 students' votes. They were Library space that inspires study and learning $(\mathrm{n}=123 ; 31.9 \%)$, the library with quiet space $(\mathrm{n}=121 ; 31.3 \%)$, and the friendly website $(\mathrm{n}=101 ; 26.2 \%)$. Moreover, there were $22(5.7 \%)$ and 16 students $(4.1 \%)$ rated that library was noisy and absolutely noisy to inspire learning and research. These findings show that although the library has created good conditions for study, some students were not really satisfied and did not value the efforts provided by the library staff. Therefore, it is recommended that library leaders should consider alternative ways to improve this situation.

Although the dimension of Copyright only consists of four evaluation criteria, 2 criteria received a low rating by a large number of students. No criterion was scored at good scale compared to the other three dimensions. More specifically, 122 students $(31.6 \%)$ rated average, $9(2.3 \%)$ rated badly, $6(1.6 \%)$ rated very badly to the criterion of Open access information. Similarly, the criterion of Contents with the experts and users' evaluations is scored at average $(\mathrm{n}=102 ; 28.6 \%)$ and badly $(\mathrm{n}=7 ; 1.8 \%)$. Therefore, the library leaders should pay more attention to raising awareness of the users of copyright and provide more information sources together with the evaluations of the experts and users.

\section{2) Factors influencing students' satisfaction of library services}

To determine the factors influencing the students' satisfaction of the library services, the Exploratory Factor Analysis (EFA) function in SPSS was used. Four dimensions with 31 observed variables (Table 3) from the updated LibQual model were presented in the suggested model of impacting factors (Figure 1).

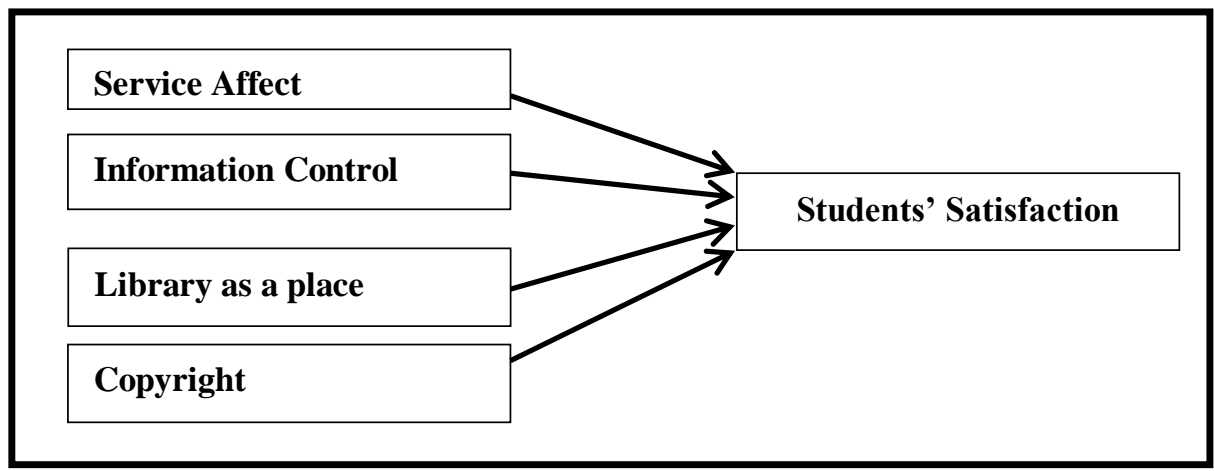


Table 3: Groups of observed factors

\begin{tabular}{|c|c|c|c|c|}
\hline No & Dimension & Observed variables & Coded & Count \\
\hline \multirow{10}{*}{1} & \multirow{10}{*}{$\begin{array}{l}\text { Service } \\
\text { Affect }\end{array}$} & Employees who instill confidence in users & SA1 & \multirow{10}{*}{10} \\
\hline & & Giving users individual attention & SA2 & \\
\hline & & Employees who are consistently courteous & SA3 & \\
\hline & & Readiness to respond to users' questions & SA4 & \\
\hline & & Employees who have the knowledge to answer user questions & SA5 & \\
\hline & & Employees who understand the needs of their users & SA6 & \\
\hline & & Willingness to help users & SA7 & \\
\hline & & Dependability in handling users' service problems & SA8 & \\
\hline & & Capacities to help users' online-study & SA9 & \\
\hline & & Employees who deal with users in a caring fashion & SA10 & \\
\hline \multirow{10}{*}{2} & \multirow{10}{*}{$\begin{array}{c}\text { Information } \\
\text { Control }\end{array}$} & The printed materials I need for my work & $\mathrm{IC} 1$ & \multirow{10}{*}{10} \\
\hline & & Print and/or electronic journal collections I need for my work & IC2 & \\
\hline & & Making e-resources accessible from my home or office & IC3 & \\
\hline & & The electronic information resources I need & IC4 & \\
\hline & & Reliable electronic resources & IC5 & \\
\hline & & Available data that allow me to work on my own & IC6 & \\
\hline & & Modern equipment that lets me easily access needed information & IC7 & \\
\hline & & Easy-to-use access tools that allow me to find things on my own & IC8 & \\
\hline & & Making information easily accessible for use & IC9 & \\
\hline & & A library Website enabling me to locate information on my own & IC10 & \\
\hline \multirow{7}{*}{3} & \multirow{7}{*}{$\begin{array}{c}\text { Library as a } \\
\text { Place }\end{array}$} & Quiet space & LP1 & \multirow{7}{*}{7} \\
\hline & & A comfortable and inviting location & LP2 & \\
\hline & & A getaway for study, learning, or research & LP3 & \\
\hline & & Library space that inspires study and learning & LP4 & \\
\hline & & Library space that inspires study and research in group & LP5 & \\
\hline & & Friendly website & LP6 & \\
\hline & & Useful website & LP7 & \\
\hline \multirow{4}{*}{4} & \multirow{4}{*}{ Copyright } & Useful information for everyone & $\mathrm{CO} 1$ & \multirow{4}{*}{4} \\
\hline & & Open access information & $\mathrm{CO} 2$ & \\
\hline & & Trust veracity of content & $\mathrm{CO} 3$ & \\
\hline & & Contents with the experts and users' evaluations & $\mathrm{CO} 4$ & \\
\hline
\end{tabular}

The four pre-prequisites of EFA performance were checked: Cronbach's Alpha reliability test, number of measurement variables, number of samples, and Bartlett and KMO (Kaiser - Meyer - Olkin measure of sampling) test. Regarding the Cronbach's Alpha reliability test (Table 4), all groups of factors have Cronbach's Alpha values > 0.7 , satisfying the first condition.

Table 4.Cronbach'Alpha test

\begin{tabular}{|l|l|c|c|}
\hline No & \multicolumn{1}{|c|}{ Dimensions } & $\begin{array}{c}\text { Observed } \\
\text { variables }\end{array}$ & Cronbach'Alpha \\
\hline 1 & Service Affect (SA) & 10 & 0.818 \\
\hline 2 & Information Control (IC) & 10 & 0.837 \\
\hline 3 & Library as a Place (LP) & 7 & 0.813 \\
\hline 4 & Copyright (CO) & 4 & 0.780 \\
\hline
\end{tabular}

The numbers of observed variables in 4 dimensions (Table 3 ) are all $>3$. Thus, it satisfied the requirements stated by Reference [17]. In particular, the number of samples is 386, which is higher than the expected minimum (50 samples) and ideal (100 samples) required by Reference [7]. In terms of the Bartlett and KMO test: The results 
DOI: $\underline{10.51386 / 25815946 / \text { ijsms-v4i4p109 }}$

Volume: 4 Issue: 4

July to August 2021

https://www.ijssmsjournal.org

of EFA (Principal components with Varimax rotation) show that $\mathrm{KMO}=0.834$ meets the requirement $0.5 \leq \mathrm{KMO} \leq$ 1 to perform EFA (Table 5); and factor analysis suitable with the research data. Furthermore, according to Reference [12]if:
KMO > = 0.90: Very good;
$0.60<=\mathrm{KMO}<0.70$ : So so;
$0.80<=\mathrm{KMO}<0.90:$ Good;
$0.50<=\mathrm{KMO}<0.60$ : Bad;
$0.70<=\mathrm{KMO}<0.80$ : Well;
$\mathrm{KMO}<0.50$ : Unacceptable

Table 5. KMO and Bartlett's Test

\begin{tabular}{|c|c|c|}
\hline \multicolumn{3}{|c|}{ Kaiser-Meyer-Olkin Measure of Sampling Adequacy. } \\
\hline \multirow[t]{2}{*}{ Bartlett's Test of Sphericity } & df & 465 \\
\hline & Sig. & .000 \\
\hline
\end{tabular}

The results of KMO and Bartlet testing (Table 5) show that KMO $=0.834>0.7$ should be good to perform EFA analysis. The result of Bartlett's test is 7764.220 with the observed variables in the population being correlated with each other at the significance level. $=0.000<0.05$. This proves that the data used for factor analysis was appropriate. Four dimensions were extracted at the eigenvalues of 1.634 and the extracted variance was $53.126 \%>$ $50 \%$ (Table 6). The loading coefficients of the variables were $>0.5$ and the study reached above the minimum sample size> 50 [7].

Table 6. Total Variance Explained

\begin{tabular}{|c|c|c|c|c|c|c|c|c|c|}
\hline \multirow[t]{2}{*}{ Component } & \multicolumn{3}{|c|}{ Initial Eigenvalues } & \multicolumn{3}{|c|}{$\begin{array}{c}\text { Extraction Sums of Squared } \\
\text { Loadings }\end{array}$} & \multicolumn{3}{|c|}{$\begin{array}{l}\text { Rotation Sums of Squared } \\
\text { Loadings }\end{array}$} \\
\hline & Total & $\begin{array}{c}\% \text { of } \\
\text { Variance }\end{array}$ & $\begin{array}{c}\text { Cumulative } \\
\%\end{array}$ & Total & $\begin{array}{c}\% \text { of } \\
\text { Variance }\end{array}$ & $\begin{array}{c}\text { Cumulative } \\
\%\end{array}$ & Total & $\begin{array}{c}\% \text { of } \\
\text { Variance }\end{array}$ & Cumulative $\%$ \\
\hline 1 & 9.750 & 31.451 & 31.451 & 9.750 & 31.451 & 31.451 & 5.846 & 18.857 & 18.857 \\
\hline 2 & 2.808 & 9.057 & 40.509 & 2.808 & 9.057 & 40.509 & 4.177 & 13.473 & 32.330 \\
\hline 3 & 2.277 & 7.345 & 47.854 & 2.277 & 7.345 & 47.854 & 4.144 & 13.367 & 45.697 \\
\hline 4 & 1.634 & 5.272 & 53.126 & 1.634 & 5.272 & 53.126 & 2.303 & 7.429 & 53.126 \\
\hline 5 & 1.549 & 4.996 & 58.121 & & & & & & \\
\hline 6 & 1.331 & 4.293 & 62.414 & & & & & & \\
\hline 7 & 1.149 & 3.707 & 66.122 & & & & & & \\
\hline 8 & 1.075 & 3.468 & 69.589 & & & & & & \\
\hline 9 & 1.070 & 3.451 & 73.040 & & & & & & \\
\hline 10 & .887 & 2.861 & 75.901 & & & & & & \\
\hline 11 & .800 & 2.581 & 78.482 & & & & & & \\
\hline
\end{tabular}

The results of EFA exploratory factor analysis with the rotation matrix (2 times) show that all of four dimensions of observed factors influenced student's satisfaction of library service quality (Table 7). However, out of 31 observed variables, three had no effect on students' satisfaction. They werePrint and/or electronic journal collections I need for my work, Library space that inspires study and research in group, and Useful website.

Table 7. Rotated Component Matrix ${ }^{\mathrm{a}}$

\begin{tabular}{|l|r|r|r|r|}
\hline & \multicolumn{3}{|c|}{ Component } \\
\cline { 2 - 5 } & 1 & 2 & 3 & \\
\hline SA 1 & .779 & & & \\
SA 7 & .732 & & \\
SA 2 & .715 & & \\
SA 8 & .694 & & \\
SA 6 & .637 & & & \\
SA 9 & .619 & & & \\
\hline
\end{tabular}


Extraction Method: Principal Component Analysis.

Rotation Method: Varimax with Kaiser Normalization.

\section{Pearson Correlations}

a. Rotation converged in 7 iterations.

Data presented in Table 8 show that there was a correlation between the dependent variable Students' satisfaction (SS) and four dimensions of independent variables (SA, IC, LP and CO) $(p=.000<.05)$. It indicates that the independent variables are linearly correlated with the dependent variable. The Pearson correlation value $(r)$ between the independent and dependent variables is positive. In other words, whenever the independent variables (Service Affect, Information Control, Library as a Place and Copyright) increase, the dependent variable (student satisfactionof the library services) also increases. Moreover, the $r$ value tends to approach 1 , indicating that the linear correlation between the independent variable and the dependent variable is strong. In particular, the Pearson correlation coefficient with the symbol ** identifies pairs of variables with linear correlation at the $99 \%$ confidence level $(p=.01)$. In terms of the strength and weakness between the independent variable and the dependent variable in the absence of other pairs of variables, Service Affect (SA) and Students' Satisfaction (SS) reach the strongest correlation ( $r=0.460)$. Library as a Place (LP) and Students' Satisfaction (SS) get the weakest correlation $(r=$ 0.191). It is worth noting that all the independent variables have a statistically significant linear correlation (Sig.= $.000<.05)$. Therefore, no independent variables were excluded in the performent of multivariate regression analysis.

Table 8. Pearson Correlations

\begin{tabular}{|ll|r|r|r|r|r|}
\hline & & SS & SA & \multicolumn{1}{c|}{ LP } & \multicolumn{1}{c|}{ IC } & \multicolumn{1}{c|}{ CO } \\
\hline \multirow{3}{*}{ SS } & Pearson Correlation & 1 & .460 & .191 & $.439^{* * *}$ & $.293^{* * *}$ \\
& Sig. (2-tailed) & & .000 & .000 & .000 & .000 \\
& N & 386 & 386 & 386 & 386 & 386 \\
& Pearson Correlation & $.460^{* *}$ & 1 & $.419^{* *}$ & $.777^{* *}$ & $.506^{* *}$ \\
SA & Sig. (2-tailed) & .000 & & .000 & .000 & .000 \\
& N & 386 & 386 & 386 & 386 & 386
\end{tabular}




\section{DOI: $\underline{10.51386 / 25815946 / i j s m s-v 4 i 4 p 109}$}

Volume: 4 Issue: 4

July to August 2021

https://www.ijsmsjournal.org

\begin{tabular}{|c|c|c|c|c|c|c|}
\hline \multirow{4}{*}{ LP } & Pearson Correlation & $.191^{* *}$ & $.419^{* * *}$ & $1 \mid$ & $.437^{* *}$ & $.530^{* *}$ \\
\hline & Sig. (2-tailed) & .000 & .000 & & .000 & .000 \\
\hline & & 386 & 386 & 386 & 386 & 386 \\
\hline & Pearson Correlation & $.439^{* *}$ & $.777^{* *}$ & $.437^{* *}$ & 1 & $.550^{* *}$ \\
\hline \multirow[t]{3}{*}{ IC } & Sig. (2-tailed) & .000 & .000 & .000 & & .000 \\
\hline & & 386 & 386 & 386 & 386 & 386 \\
\hline & Pearson Correlation & $.293^{* *}$ & $.506^{* *}$ & $.530^{* *}$ & $.550^{* *}$ & 1 \\
\hline \multirow[t]{2}{*}{$\mathrm{CO}$} & Sig. (2-tailed) & .000 & .000 & .000 & .000 & \\
\hline & $\mathrm{N}$ & 386 & 386 & 386 & 386 & 386 \\
\hline
\end{tabular}

**. Correlation is significant at the 0.01 level (2-tailed).

\section{Influencing level of dimensions}

To determine the influencing level (strong or weak, positive or negative) of the dimensions on the students' satisfaction of the library service quality, multivariate regression analysis was conducted. Multivariate regression is a method of estimating a single regression model with one or more independent variables. Whenever the regression model includes many dependent variables, it is called multivariable regression [7]. Thus, multivariate regression analysis in SPSS will help determine if the factors affect or do not affect students' satisfaction of the library service quality.

Regression model among 4 groups of independent variables (1) Service Affect (SA); (2) Information Controll (IC); (3) Library as a Place (LP); (4) Copyright (CO); and the dependent variable Students' satisfaction (SS) is shown in the following tables:

Table 9. Model Summary ${ }^{\mathrm{b}}$

\begin{tabular}{|l|r|r|r|r|r|}
\hline Model & R & R Square & Adjusted R Square & $\begin{array}{c}\text { Std. Error of the } \\
\text { Estimate }\end{array}$ & Durbin-Watson \\
\hline 1 & $.481^{\mathrm{a}}$ & .231 & .223 & .46161 & 2.051 \\
\hline
\end{tabular}

a. Predictors: (Constant), CO, SA, LP, IC

b. Dependent Variable: HL

$R$ value in Table 9 is 0.481 , indicating that the correlation between the variables in the model is very close. The value of $R 2$ (R Square) is 0.231 , indicating the appropriateness of the model to the population. The adjusted $R$ value of 0.223 means that there is a linear regression model between four groups of independent variables and students' satisfaction.

Table 10. ANOVA ${ }^{\mathrm{a}}$

\begin{tabular}{|rl|r|r|r|r|r|}
\hline Model & \multicolumn{1}{|c|}{ Sum of Squares } & \multicolumn{1}{c|}{ df } & Mean Square & F & Sig. \\
\hline \multirow{3}{*}{1} & Regression & 24.424 & 4 & 6.106 & 28.655 & \\
& Residual & 81.185 & 381 & .213 & & \\
& Total & 105.609 & 385 & & & \\
\hline
\end{tabular}

a. Dependent Variable: HL

b. Predictors: (Constant), CO, SA, LP, IC

The results of the ANOVA analysis of variance show that the F-value was 28.655 with Sig. $=0.000(<0.05)$ (Table 10). This means that the regression model fits the collected data and that the variables were statistically significant. Statistically significant linear relationship $(\mathrm{p}<0.05)$ also shows that the independent variables in the model have a relationship with the dependent variable Students' satisfaction. 


\begin{tabular}{|c|c|c|c|c|c|c|c|c|}
\hline \multicolumn{9}{|c|}{ Table 11. Coefficients ${ }^{\mathrm{a}}$} \\
\hline \multirow{2}{*}{\multicolumn{2}{|c|}{ Model }} & \multicolumn{2}{|c|}{$\begin{array}{l}\text { Unstandardized } \\
\text { Coefficients }\end{array}$} & \multirow{2}{*}{$\begin{array}{c}\begin{array}{c}\text { Standardized } \\
\text { Coefficients }\end{array} \\
\text { Beta }\end{array}$} & \multirow[t]{2}{*}{$\mathrm{t}$} & \multirow[t]{2}{*}{ Sig. } & \multicolumn{2}{|c|}{ Collinearity Statistics } \\
\hline & & $\mathrm{B}$ & Std. Error & & & & Tolerance & VIF \\
\hline \multirow{5}{*}{1} & (Constant) & 2.384 & .202 & & 11.774 & .000 & & \\
\hline & SA & .304 & .074 & .297 & 4.099 & .000 & .384 & 2.602 \\
\hline & LP & -.039 & .040 & -.052 & -.963 & .336 & .683 & 1.464 \\
\hline & IC & .184 & .070 & .197 & 2.637 & .009 & .361 & 2.772 \\
\hline & $\mathrm{CO}$ & .049 & .046 & .062 & 1.058 & .291 & .588 & 1.702 \\
\hline
\end{tabular}

a. Dependent Variable: SS

The regression coefficients show the general significance level of the Sig components. $=0.000(<0.05)$. This proves that all independent variables have an impact on Students' satisfaction. The components in Students' satisfaction are significant in the model (except 2 dimensons LP \& CO) and have a positive impact on Students'satisfaction, because the regression coefficients are all significant (except for the dimension LP). Reference [8] said that if $\mathrm{VIF}<10$, there is no multicollinearity. However, the independent variables LP and CO with Sig. = .336 and Sig. $=.291(\mathrm{p}>.05)$ have no statistical significance. It is possible that these two independent variables contain observed variables that influence each other. Therefore, these two independent variables are excluded from the regression model. So, the standardized regression equation model is: SS $=0.297^{*} \mathrm{SA}+0.197 * \mathrm{IC}$

The regression model shows that both independent variables (SA and IC) have a positive influence on Students' satisfaction at the reliability of $11.774 \%(\mathrm{t}=11.774)$. This means that if the independent variable SA increases 1, the students' satisfaction will increase 0.279. Similarly, when the Information Controll increases 1 point, the students' satisfaction will increase 0.197 points.

The Standardized Coefficients Beta indicates the strong or weak influence between two independent variables on the dependent variable. If the Beta value is large, the influence of that independent variable is strong. Thus, in two independent variables that affect the students' satisfaction, Service Affect (SA) is the strong group of influencing factors with Beta of .297 and Information Controll (IC) is the weak group of impacting factors withBeta of.197 (Table 11).

\section{CONCLUSION AND RECOMMENDATIONS}

The findings from this current study show that among 31 updated LibQual criteria of service quality evaluation, five criteria were rated very well and 26 were ranked well by students. Moreover, the study found all of the four groups of factors influencingthe quality of library services. These were identified asService Affect, Information Controll, Library as a Place and Copyright. Of the four, Service Affectwas reported as the strong group of influencing factors and Information Controll the weak group that influenced students' satisfaction. Besides these evaluations, some problems were identified; therefore, there are some recommendations for improving the quality of library services.

\section{For library leaders}

It is recommended that library leaders should improve the quality of Reference Service (Ask me!). The Reference staff is encouraged to be available to answer all types of questions generated by the students while using library services or resources. Particularly, library staff should be trained with in-depth knowledge of the field, communication skills and user supporting capacity. Library staff should behave students in more friendly and collaborative ways in order to improve the existing situation at the Reference Desk.

Library leaders should consider the existing searching tools and their simple functions provided to the users. More specifically, library needs to have One Search tool so that the users can access information, save time, 
effort and enthusiasm in searching resources. Moreover, library should conduct more information literacy courses to train the students how to explore the information on the library website. In addition, a library website design contest should be launched to attract students' creatice ideas to innovate the current library website with more friendly and useful functions to the users.

More learning space should be set up at the library to inspire student learning and research. It is advisable to organize exchanges and visits to research libraries in the country so that library staff can initiate more ideas for the intellectual space. Students are encouraged to access fulltexts from respository resources so that they can have an overview or deepen understanding of the field they are investigating for better products. However, they are advised to follow the copyright before reading, sharing and downloading information with their peers or writing for publications.

\section{For the library staff}

It is recommended that library staff should improve their own abilities in service quality and student-related factors to support student learning online and satisfy students' academic needs and interests. They are encouraged to use online learning support softwares and electronic databases and introduce to students. Their attitudes, commitment and willingness to communicate or support students are potential ways to involve students in expanding the accessible services that promote students to build on their knowledge in the learning process.

\section{REFERENCES}

[1] Bui, T. T. D. (2015). Phan tich cac khoang cach trong danh gia chat luong dich vu thu vien theo mo hinh SERVQUAL [Analysis of gaps in the assessment of library service quality by SERVQUAL model]. Journal of Vietnamese libraries(3), 34-38.

[2] Bui, T. T. D. (2016). Tim hieu mot so mo hinh danh gia chat luong dich vu Thong tin - Thu vien dua tren quan diem nguoi su dung dich vu [Introduction to some information - library service quality evaluation models based on the users' perspectives]. Journal of Information and Documentation(1), 37-43.

[3] Bui, T. T. D. (2018). Xay dung cac tieu chi danh gia chat luong dich vu thong tin - thu vien tai thu vien cac truong dai hoc o Viet Nam [Developing criteria for library and information service quality evaluation at academic libraries in Vietnam]. Journal of Vietnamese libraries(1), 32-40.

[4] Calvert, P. J., \& Hernon, P. (1997). Surveying service quality within university libraries. Journal of Academic Librarianship, 23(5), 408415.

[5] Cook, C., Heath, F., \& Thompson, B. (2003). Zone of tolerance in perception of library service quality: A LibQUAL Study. portal: Libraries and the Academy, 3(113-123).

[6] Dahan, S. M., Taib, M. Y., Zainudina, N. M., \& Ismail, F. (2015). Surveying users' perception of academic library services quality: A case study in Universiti Malaysia Pahang (UMP) Library The Journal of Academic Librarianship, 42 (2016), 38-43.

[7] Hair, J. F., Black, W. C., Babin, B. J., \& Anderson, R. E. (2009). Multivariate data analysis (7th ed.). Englewood Cliffs: Prentice Hall International.

[8] Hoang, T., \& Chu, N. M. N. (2008). Data analysis with SPSS. Ho Chi Minh City, Vietnam: Hong Duc.

[9] Huynh, V. M. (2013). Su dung thang do ServQual de danh gia chat luong dich vu thu vien dai hoc [Assessment of academic library service quality by ServQual model]. Journal of Information and Documentation(2).

[10] Iroaganachi, M. A., \& Nkik, C. (2016). Performance assessment model for academic libraries: The Covenant University Library example. Annals of Library \& Information Studies, 63(1), 7-15. Retrieved from https://ezproxy.deakin.edu.au/login?url=https://search.ebscohost.com/login.aspx?direct=true \&db=lls\&AN=114390142\&authtype=sso\&cus tid=deakin\&site=eds-live $\&$ scope $=$ site

[11] Johari, R., \& Zainab, A. N. (2007). Identifying what services need to be improved by measuring the library's performance. Malaysian Journal of Library \& Information Science, 12(1), 35-53.

[12] Kaiser, H. (1974). An index of factor simplicity. Psychometrika, 39, 31-36.

[13] Krejcie, R. V., \& Morgan, D. W. (1970). Determining sample size for research activities. Educational and Psychological Measurement, $30,607-610$. 


\section{DOI: $\underline{10.51386 / 25815946 / i j s m s-v 4 i 4 p 109}$}

Volume: 4 Issue: 4
July to August 2021 https://www.ijsmsjournal.org

[14] Miller, K. F. (2008). Service quality in academic libraries: An analysis of LibQual ${ }^{\mathrm{TM}}$ scores and institutional characteristics. (Ph.D. dissertation), College of Education, University of Central Florida Orlando, Florida.

[15] Ngo, T. K. D., \& Nguyen, T. M. T. (2017). Chat luong dich vu thu vien: Nghien cuu thuc nghiem tai mot so truong dai hoc o dong bang song Cuu Long [Library service quality: A case study of some universities in the Mekong Delta. Tap chi Khoa hoc Truong Dai hoc An Giang [An Giang University Journal of Science], 18(6), 110-120.

[16] Nguyen, T. M. T., \& Tran, X. T. H. (2010). Chat luong dich vu thu vien so sanh giua hai mo hinh: Chat luong ky thuat/ chuc nang va SerQual [Library service quality - comparison between two models: technical/functional quality and ServQual]. Tap chi phat trien KH\&CN [Journal of Science and Technology Development], 13(1), 62-73. Retrieved from http://dlib.dnpu.edu.vn/doc/chat-luong-dichvu-thu-vien-so-sanh-giua-hai-mo-hinh-chat-luong-ky-thuat-chuc-nang-va-servqual-471285.html

[17] Stevens, J. P. (2002). Applied multivariate statistics for the social sciences (4 ed.). Mahwah, NJ: Lawrence Erlbaum Associates.

[18] Zare Mehrjerdi, Y., Sayyadi Toranlo, H., \& Jamali, R. (2009). Measuring academic libraries service quality in fuzzy environment. Performance Measurement and Metrics, 10(2), 94-115. doi:10.1108/14678040911005437 